\title{
レーザーと放射光による2光子励起分光法
}

\author{
辻林 徹 \\ 大阪歯科大学 物理学教室 ( ₹573-1121 大阪府枚方市楠葉花園町8-1)
}

\section{Two-Photon Spectroscopy Using Laser Light and Synchrotron Radiation}

\author{
Toru TSUJIBAYASHI \\ Department of Physics, Osaka Dental University, 8-1 Kuzuha-hanazono, Hirakata, Osaka 573-1121
}

(Received February 10, 2006)

\begin{abstract}
The accessibility of the two-photon spectroscopy to the forbidden states of the one-photon transition makes it a powerful tool. The two-photon excited core excitons were chosen as an example of a combinational use of laser light and synchrotron radiation. The experiments were performed at Beamline 1B of UVSOR, Institute for Molecular Science. The two light sources were synchronized at a repetition rate of $90 \mathrm{MHz}$. The singlephoton counting method was used for detecting luminescence as the signal of two-photon absorption by the sample. The two-photon excitation spectrum of Auger-free luminescence from the $\mathrm{BaF}_{2}$ crystal exhibits several peaks due to core excitons. The analysis of the spectrum reveals the spin-orbit splitting and dispersion of the $4 f$ and $6 p$ states of the $\mathrm{Ba}$ ion in $\mathrm{BaF}_{2}$. The lifetime of the core exciton is obtained from the time-resolved measurements.
\end{abstract}

Key Words: Two-photon spectroscopy, Core exciton, Auger-free luminescence, $\mathrm{BaF}_{2}$

\section{1.はじめに}

この稿では, レーザー光と放射光を励起光として内殼 電子による2光子吸収を固体内に起こさせ，物質の非占有 状態の分布を探る実験1)について紹介する．非占有状態の 情報は，物質の励起一脱励起サイクルを調べる際に欠か せない．励起状態の時間変化を調べた実験2)についてもあ わせて紹介する。一般に, 価電子や内殼電子の軌道はs 軌 道や $p$ 軌道であることが多いのに対し，最近の関心は，そ の外側の $d$ 軌道や軌道といった角運動量が大きい状態に集 まっている。通常の光吸収における双極子遷移では角運 動量の変化は土1であるが，2光子遷移の選択則では土2の 遷移が許容であるので，d軌道やf軌道を調べるのに2光子 吸収の手法は威力を発揮すると期待できる。

非占有状態を調べて得られることは，単なる状態分布 にとどまらない．固体では同等な電子準位がエネルギー バンドを形成する。一方， $d$ 軌道や $f$ 軌道は $s$ 軌道や $p$ 軌道と 比べて局在性が強いので，バンド形成の効果が表面上は 見えてこない場合があるかも知れない。すなわち，工ネ ルギーバンドを形成すれば， $\boldsymbol{k}$-分散が生じ， $\boldsymbol{k}=0$ ( (点)以 外の状態が関与した遷移による寄与が観測されるはずで あるが，逆に，準位の分裂が観測されたとしても，これ を孤立原子が受けるまわりの原子が形成する結晶場の影 響として説明できそうである。内殼電子は孤立性が特に 強いと思わ机るので，内殼電子の $d$ 軌道や軌道への励起に
対して，バンドモデルと結晶場近似のどちらの描像が有 効であるかは大変興味深い問題である。

2光子分光法の発展は，20世紀最大の科学上の発明であ るレーザーの発達と軌を一にしてきたことは言うまでも ない3)．1960年代のキセノンランプとルビーレーザーによ る実験から，1970年代には発振波長可変の色素パルス レーザーを使った実験へと進んだ。このことにより，そ れまでは大きな一つの構造として観測されていた吸収帯 の中に埋もれていた微細な構造を浮き出させることがで きた。

放射光施設は，20世紀後半における科学上のもう一つ の大きな発明であり，分光学に対する影響の大きさは レーザーに勝るとも劣らない。はじめは素粒子実験用の 加速器を間借りして使っていたが，専用施設として建設 されだしたのが，1970年代後半である．現在ではこの特 集の他の記事にも詳しく述べられているように，レー ザーと放射光の併用実験は大きな広がりを見せつつある

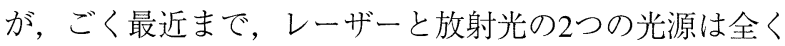
と言っていいほど異なる性質を持っていると認識されて いた．2光子吸収における併用実験の報告は非常に少ない ものの，1980年代前半には組み合わせ実験の報告が見ら れるようになった 4,5$)$. 繰り返しが $1 〜 100 \mathrm{MHz}$ 程度のパル ス光源である放射光に対し, 繰り返しが $100 \mathrm{~Hz}$ 以下の窒素 レーザーやNd:YAGレーザーが初期の実験には使われた。 強烈なレーザー光が連続的に試料に当たった状態は，実 
験条件として好ましいことではない.レーザー光が必要 なときにだけ照射されるためには，放射光のパルスと同 期させる必要がある．1980年代後半のモードロックレー ザーの出現は両者の時間軸上の特性を非常に似通ったも のにさせた。高繰り返しのパルス列という点では両者は 同じであるから, 周波数と位相をそろえれば, $2 つ 0$ 光源 を完全に同期させて使うことが可能になったのである.

時間軸上の特性とは対照的に, 波長軸上の特性におけ る2つの光源の違いは依然として大きいままである．放射 光は赤外からX線まで非常に広範囲の分布をもつ光源であ る. 一方，1990年頃に利用可能となった Ti:Sapphireレー ザーやその他のレーザーを基本にした倍波発生やラマン レーザーといった手法により，レーザーの発振領域もX線 領域に達している。しかしながら, 放射光が連続分布を 持つのに対して，レーザーの発振波長は離散的である. 得られる光の強度についてはレーザーが放射光を大きく 凌駕している．1990年代後半に作られた第3世代といわれ る放射光施設では, 大きな輝度の得られる挿入光源を入 れたビームラインの比重が増しているが，扦入光源にお いて波長を連続掃引する測定を実施することは, 簡単で ないようである。

我々は自然科学研究機構分子科学研究所の放射光施設 UVSORのBL1Bで，1995年からほぼ10年にわたって，レー ザーと放射光の組み合わせ実験をおこなってきた1,2,6-9).

このビームラインは従来型の偏向電磁石を用いたライン である，以下では，この実験システムを使用した，発光 検出による2光子吸収の測定実験について紹介する.

\section{2. 実験装置}

Fig. 1は実験配置図である7,9). 放射光は瀬谷・波岡型分 光器を通して単色化される。もう一つの光源として, モードロックTi:Sapphire レーザーを800 nm $(1.55 \mathrm{eV})$ で発 振させて用いた。基本波をそのまま励起光として使う他 に，倍波ユニットを入れて $400 \mathrm{~nm}(3.10 \mathrm{eV})$ の光源として も使用した。レーザー光の強度はそれぞれ，約 $90 \mathrm{~mW}$ と 20 $\mathrm{mW}$ あ゙あた.レーザー光は50 mの長さの光ファイバを 通って測定用ポートに導かれる。ファイバの出口には光 学シャッターを配置し, 試料への入射を制御した. 試料 で2光子吸収が起こったことは，放射される発光で検出す

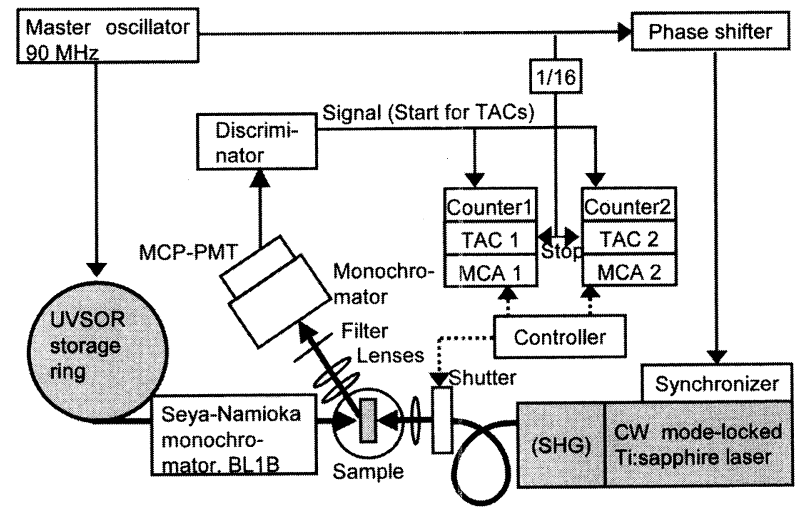

Fig. 1 The experimental setup.
る.目的の発光だけを観測するため, 光学フィルターと 分光器で発光以外の光を除去し，マイクロプレート型の 光電子増倍管 (MCP-PMT)で発光を受ける. 発光を受ける たびにMCP-PMTはパルスを発し，カウンターで計数され る。レーザーを入れたときと, 入れないときの計数の差 が2光子吸収による信号である。発光は積算量だけでな く, 単一光子計数法により時間変化も同時に記録され る，時間応答測定に関する詳細は第4節で述べることにす る.レーザーパルスは電子機器 (Fig. 1のphase shifterと synchronizer)により放射光パルスと同期される.

2光子吸収は1光子吸収に比べて低い確率でしか起こら ない. 強度の十分強いレーザー光のみによる2光子励起の ときは, 中間状態が透明領域にあっても，2光子吸収を観 測可能な強度で起こすことができる，ところが，今回の 実験における放射光の強度は単位時間あたりに試料に到 着する光子数にしてレーザーの約 $10^{-7}$ と遙かに弱いため に，中間状態が実状態である共鳴型の吸収になるように2 つの光の波長が選ばれていなければならない. 中間状態 が透明領域にある場合には，1光子吸収が原因となる信号 は観測されない.ところが，共鳴条件下では中間状態に よる1光子吸収が原因の信号も観測されるため, レーザー をオン/オフして差をとる必要が生じる，また，レーザー の波長を変えて観測することが, 2 光子吸収過程と他の過 程を弁別することに役立つ.もちろん，レーザー光だけ の2光子吸収により別の発光が生じて肝心の発光の観測を 妨げないように波長を選ぶことも必要である.

放射光とレーザー光は試料の表側と裏側から照射し た. 光が入射する試料の $2 つ の$ 面は䢃開 (または研磨)して 使用した。内殼電子が2光子励起されたことを見るため に，オージェフリー発光を検出した. Fig. 2に示したよう に, オージェフリー発光は最も外側の内殼電子準位が比 較的浅い場合に観測される ${ }^{10)}$ 。すなわち, Fig. 2 (a)のよ うに内殼電子準位が深い場合は, 内殼正孔が価電子と再 結合するとともに他の価電子を励起する，いわゆるオー ジェ過程が起こるが，Fig. 2 (b)のように内殼準位が浅い 場合の再結合エネルギーは発光として放出される.これ がオージェフリー発光である。この発光が観測される物 質は, $\mathrm{LaF}_{3}, \mathrm{BaY}_{2} \mathrm{~F}_{6}, \mathrm{KF}$ などのフッ化物や $\mathrm{CsF}, \mathrm{CsCl}$, $\mathrm{CsBr}$ な゙のセシウムハライドなどで，以下で紹介するの (a)

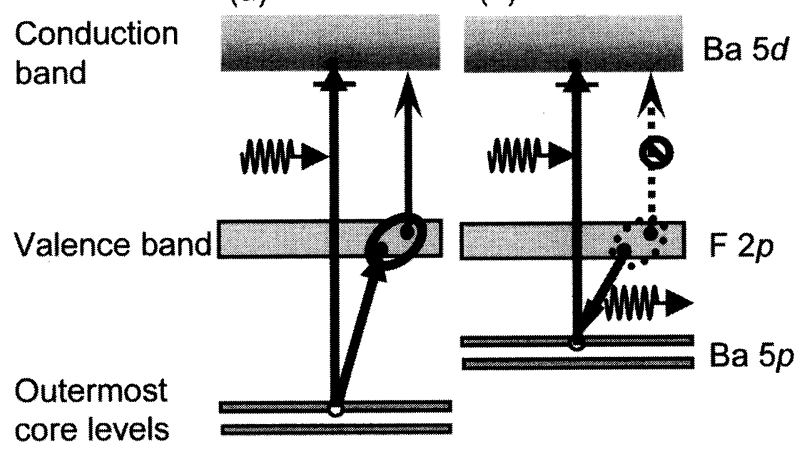

Fig. 2 (a) A schematic energy diagram of a material without Auger-free luminescence and (b) that of the crystal of $\mathrm{BaF}_{2}$, which has the Auger-free luminescence. 
はフッ化バリウム $\left(\mathrm{BaF}_{2}\right)$ についての実験である。フッ化 バリウム結晶は無色透明で，高エネルギー物理学におい て，シンチレーターとして用いられてきた。価電子帯は 主にフッ素の $2 p$ 軌道から，伝導帯は主にバリウムの $5 d$ 軌 道から成っている。

\section{3. 測定結果と考察}

\section{1 スピン・軌道分裂幅}

Fig. 3はフッ化バリウムの内殼 $5 p$ 電子の 2 光子吸収が原因 となったオージェフリー発光の励起スペクトルである1). 測定されるピークは励起子によるものである。1光子吸収 によるオージェフリー発光の励起スペクトルの立ち上が りは $17.7 \mathrm{eVであり，これは} 5 p-5 d$ 遷移に相当する. 反射ス ペクトルにおける $5 p-5 d$ 最低励起子エネルギーは $17.2 \mathrm{eV} て ゙$ あるので，この励起子の束縛エネルギーは $0.5 \mathrm{eV}$ あ゙ある.

Fig. 3内のレベル図では測定した励起子ピークとの対応が わかりやすいように，励起子束縛エネルギーも込めて描 いてある. 後のFig. 4のレベル図9）についても同様であ る.ゼロは $5 p_{3 / 2}$ 軌道の厂点に取った。これらのレベル図を 得るためには， $5 p$ 軌道や $4 f$ 軌道のスピン一軌道分裂幅を知 る必要がある．測定で得られたスペクトルを解析する前 に，まず，水素原子様モデルにおいてこれらの值を調べ ることにする11).

相対論的量子論によれば，中心対称静電場めにおけるス ピン軌道相互作用のハミルトニアン $H_{\mathrm{LS}}$ は， $\hbar=c=1$ とす る自然単位系 (れはプランク定数を $2 \pi て ゙$ 割ったもの，cは光 速度)において，次式で与えられる。

$$
H_{L S}=\frac{e}{2 m^{2} r} \frac{d \phi}{d r} s l
$$

ここで, $e, m$ は電子の電荷と質量, $s, l$ は電子のスピンと 軌道角運動量演算子， $r$ は中心からの距離である。中心 電荷 - Zeの原子核がある場合には，そのポテンシャルエネ ルギーは $\phi=-Z e / r て ゙$ 表される。この期待值を固有状態 $(n$, l)について計算すると,

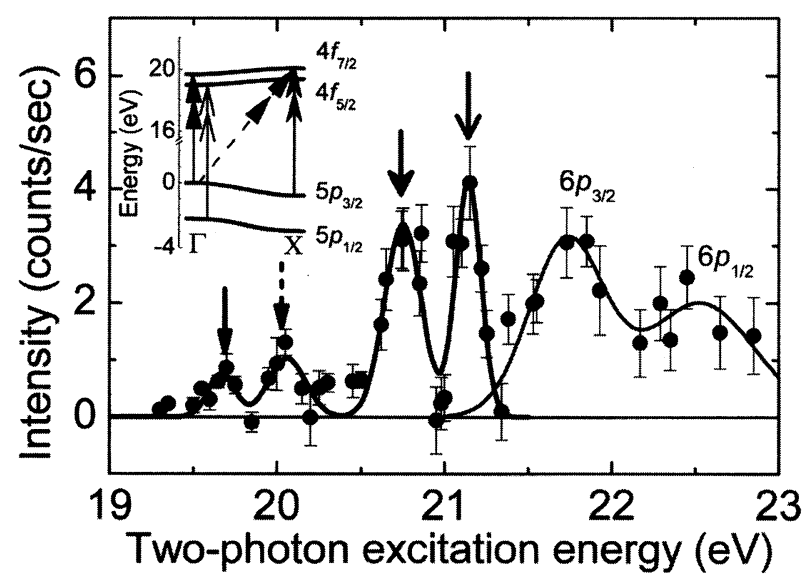

Fig. 3 The two-photon excitation spectrum of Auger-free luminescence of $\mathrm{BaF}_{2}$ using synchrotron radiation and laser.

$$
\begin{aligned}
\left\langle H_{L S}\right\rangle_{n, l} & =\frac{e}{2 m^{2}}\left\langle\frac{Z e}{r^{3}}\right\rangle_{n, l}\langle s \boldsymbol{l}\rangle \\
& =\frac{Z \alpha}{2 m^{2}} \frac{(Z \alpha m)^{3}}{n^{3} l(l+1)(l+1 / 2)}\langle s \boldsymbol{l}\rangle
\end{aligned}
$$

(2)式により， $(n, l)$ 状態のスピン二重項のエネルギー差 $\Delta_{n, l}$ は,

$$
\Delta_{n, l}=Z^{4} \alpha^{2} \frac{\alpha}{2 a_{0}} \frac{1}{n^{3} l(l+1)}
$$

ただし。

$$
a_{0}=1 / m \alpha, \quad \alpha=e^{2}\left(=e^{2} / \hbar c\right)
$$

である。（3）式を原子に適用するときのZには，原子番号 そのものではなく, $(n, l)$ 状態より内側の電子が原子核を 遮蔽する効果を考慮した值を代入する必要がある。最も 外側の内款電子や価電子，伝導電子の準位を考えるとき には，この遮蔽効果が一定であるとして，次のように， $\Delta_{n, l}$ の相対值を得ることができる。

$$
\Delta_{n, l} \propto\left(n^{3} l(l+1)\right)^{-1}
$$

(3') 式を使って， $5 p ， 5 d, 4 f, 6 p$ 軌道のスピン・軌道分裂 幅について相対比を求めると,

$$
\Delta_{5 p}: \Delta_{5 d}: \Delta_{4 f}: \Delta_{6 p} \approx 3.0: 1.0: 1.0: 1.7
$$

となる. $5 p$ 準位の分裂幅は実験的に $2.2 \mathrm{eV}$ と求められてい るので12)，他の状態については，

$$
\begin{aligned}
\Delta_{5 d} & =0.73 \mathrm{eV} \\
\Delta_{4 f} & =0.73 \mathrm{eV} \\
\Delta_{6 p} & =1.2 \mathrm{eV}
\end{aligned}
$$

となる。

3.2 フッ化バリウムにおける反射スペクトルの再考 3.1節の計算で求められた $5 d$ 状態の分裂幅はフッ化バリ ウムにおける $5 d$ 内凯励起子の反射スペクトルの従来の解 釈13,14)について疑問を投げかけることとなった。フッ化 バリウムにおける最初の精密な内殼励起子反射スペクト ルの測定は1972年に報告されている ${ }^{13)}$ ，そのスペクトル は基本的に現在我々が測定して得られるスペクトルと同 じであり，Fig. 4の上部に示されている．5p-5d内殼励起子 のピークが17.2，18.0，18.7，19.2，20.0 eVに観測され る. 文献13)における解釈を模式的に示すとFig. 4 (a)のよ うになる. $18.7 \mathrm{eV}$ のピークは小さいのでひとまず考察か ら除外すると，他の4つのピークは，互いに0.8 eV離れた 対が， $2.0 \mathrm{eV}$ 離れて2つあるように見える．前者をバンド 理論に基づいた $k$ 分散，後者を内殼 $5 p$ 軌道と $5 d$ 軌道の分裂 幅の差に帰着したのがこの解釈である．5p軌道の分裂幅 は $2.2 \mathrm{eVであるので，このモデルでは} 5 d$ 軌道の分裂幅は 0.2 $\mathrm{eV}$ となる。

ひとまずバンド理論を離れ，クラスターモデルで説明 を試みる ${ }^{14)}$. $\mathrm{O}_{\mathrm{h}}$ 群の結晶場の下では $d$ 軌道は $d_{\varepsilon}$ と $d_{\gamma}$ のつの 準位に分裂するので， $\boldsymbol{k}$ 分散で「点とX点を考えるかわり 


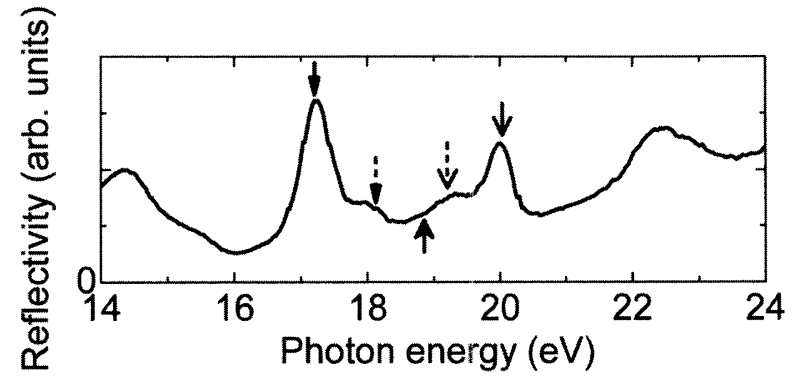

(a)

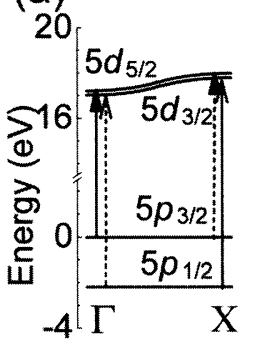

(b)

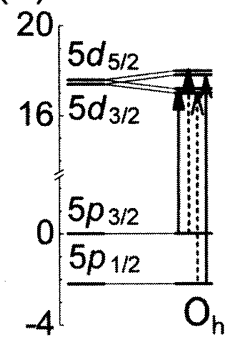

(c)

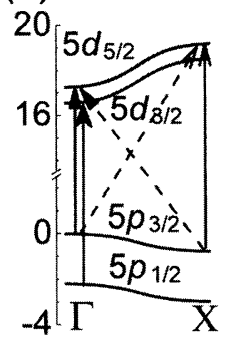

Fig. 4 (The upper panel) The reflectivity spectrum of $\mathrm{BaF}_{2}$ in the $5 p-5 d$ core exciton absorption region. (The lower panels) Schematic energy diagrams based on different models.

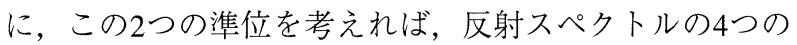
ピークを説明できる. Fig. 4 (b) は結晶場分裂が $0.8 \mathrm{eV}$ と仮 定した場合の模式図であり，5d軌道の分裂幅は(a)の場合 と全く同様に $0.2 \mathrm{eV}$ となる。

結局, Fig. 4 (a) と (b) で表されるモデルでは $5 d$ 軌道の分 裂幅という点からは全く同様に $0.2 \mathrm{eV}$ という值が得られ る.これは(6)の值に比べて小さすぎる。ここで，もう一 度，反射スペクトルを各ピークの相対強度に気をつけな がら見てみると, 4つのピークのうちの両端のピークが他 より強いことがわかる．そこで，これらはすべて $5 p_{3 / 2} \rightarrow$ $5 d_{5 / 2}$ の遷移であるとし， $5 p_{3 / 2}$ と $5 d_{5 / 2}$ の 2 つの準位の分散が それぞれ $0.8 \mathrm{eV}$ と $2.0 \mathrm{eV}$ であると仮定する。両端のピーク

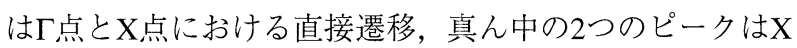
$\rightarrow \Gamma, \Gamma \rightarrow X$ の間接遷移であると考えると, ピーク間のエネ ルギー差が簡単に説明できる。実際, 最近のバンド計算 によると ${ }^{15)}, 5 p$ 軌道の分散が $0.8 \mathrm{eV}, 5 d$ 軌道の分散が約 2

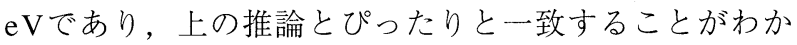
る。そこで，これまで考察の対象から除外していた 18.7 $\mathrm{eV}$ のピークは, $5 p_{1 / 2} \rightarrow 5 d_{3 / 2}$ のГ励起子に相当するものとし てみると, $5 p$ 軌道と $5 d$ 軌道の分裂幅の差が $1.5 \mathrm{eV}$ とるの で， $5 d$ 軌道の分裂幅は $0.7 \mathrm{eV}$ となり，(6)と一致する. Fig. 4 (c) はこれらのことを図で示したものである.

\section{3 フッ化バリウムにおける $5 p$ 電子の 2 光子励起ス ペクトルの解釈}

(6)で与えられるスピン・軌道分裂幅に基づいて, Fig. 3 のスペクトルのピークに解釈を与えることにする. Fig. 3 には, 19.7, 20.1，20.8，21.1 eVの比較的幅の狭い4つの

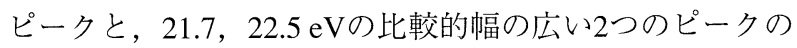
合計6つのピークが確認できる。まず，低エネルギー側の 幅の狭い 4 つピークについて考察する．挿入図に示され
ているように，最も明確に現れると予想されるピークは 点における $5 p_{3 / 2} \rightarrow 4 f_{7 / 2}$ と $5 p_{1 / 2} \rightarrow 4 f_{5 / 2}$ の直接遷移に対応する ものである：二つのピークのエネルギー差は (6)により 1.5 $\mathrm{eV}$ と求められる. 1番目 $(19.7 \mathrm{eV})$ と4番目 $(21.1 \mathrm{eV})$ のピー クの差がこの值にほぼ一致するので，19.7 eVのピークは $5 p_{3 / 2} \rightarrow 4 f_{7 / 2}$ のГ点における直接遷移, $21.1 \mathrm{eV}$ のピークは $5 p_{1 / 2} \rightarrow 4 f_{5 / 2}$ のГ点における直接遷移に対応すると考えられ る. Г点における直接遷移の次に強いであろうと思われる のはX点での直接遷移である。3.2節で求めたように， $5 p$ 軌道の分散が $0.8 \mathrm{eVであるので,} 20.1 \mathrm{eV}$ のピークはこれに 該当しない. むしろ，20.8 eVのピークがこれに対応する ものと考えられる. $20.1 \mathrm{eV}$ のピークは $\rightarrow \mathrm{X}$ の間接遷移に よると考え, $4 f$ 準位の分散を $0.4 \mathrm{eV}$ とるとつじつまが合 う.

一方, 高エネルギー側の二つの幅が広いピークは $6 p$ 軌 道への遷移 $5 p_{3 / 2} \rightarrow 6 p_{3 / 2}$ と $5 p_{1 / 2} \rightarrow 6 p_{1 / 2}$ と考えることが出来 る.二つのピークの差の $0.8 \mathrm{eV}$ は $\Delta_{5 p}-\Delta_{6 p}$ に相当するので, $6 p$ の分裂幅は $1.4 \mathrm{eV}$ となるこの值は (6)の值の $1.2 \mathrm{eV} よ り$ やや大きいが, Fig. 3のスペクトルは高エネルギー側では 精度が劣るので, 測定誤差の範囲内でつじつまが合って いると言える。

内殼電子の 2 光子励起スペクトルの解析は，これまでの 反射スペクトルの解釈にも変更を強いた。 さらに, 内殼 準位や孤立性が強い準位であっても分散が無視できない ほど大きい場合があり, 状態の正確な記述のためにはバ ンド描像によることが必要であることが確認された。

\section{4. 時間応答の測定}

\section{1 実験手法}

キセノンランプとルビーレーザーの組み合わせで行わ れた初期の 2 光子吸収の実験と, 今回の放射光と Ti:Sapphireレーザーの組み合わせ実験とを比較したときに，キ セノンランプと放射光とで掃引できる波長領域が大きく 異なることはもちろんであるが, 最も重要な違いは, 励 起光の時間特性にある. すなわち, 2 つの励起光パルスを 制御した時間分解測定が可能になったのである. Fig. 1の 測定装置のブロック図に描かれているように，励起パル スと発光の光子が到着するまでの時間を時間波高変換器 (Time-to-Amplitude Converter, TAC) で測り, 測定された 時間に応じて多チャンネル分析器 (Multi-Channel Analyzer, MCA)の該当チャンネルに1事象ずつ計数していく(単一光 子計数法).このようにして, Fig. 1で示した装置では第3 節で考察した静的な特徵を表す時間積分励起スペクトル に加えて, 内殼励起子の動的な振る舞いをも測定するこ とができる. TACの時間分解能は $10 \mathrm{ps}$ 程度あるが，測定 システムの時間分解能は励起パルスの幅に大きく左右さ れる. UVSORにおけるシングルバンチ運転時のパルス幅 はFig. 5の下部に破線で示されているように0.6 nsであっ た。レーザーパルスの時間幅はレーザー本体の出射口で は0.1 psであるが，Fig. 5の下部に実線で示されているよう に，50 mの長さのファイバを通過中に $0.3 \mathrm{~ns}$ まて広がっ た.コンボリューション解析を使った今回の測定系の分 


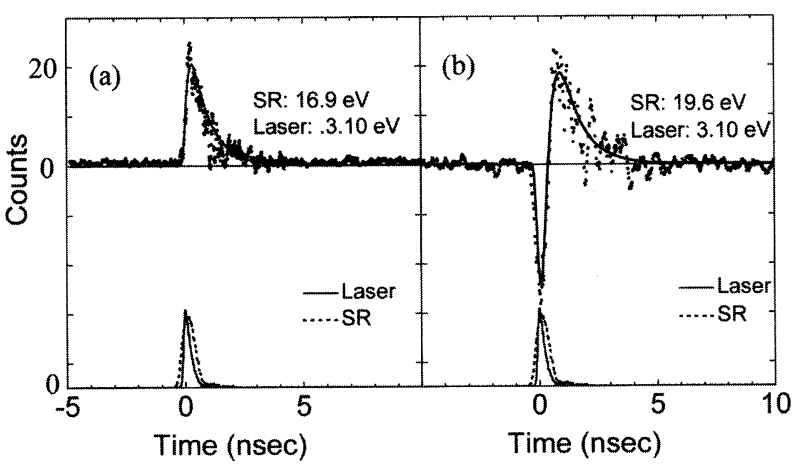

Fig. 5 Time-responses of laser-induced (and laser-depressed) Auger-free luminescence.

解能は0.1 ns 程度である。

時間分解能を向上させる方策として，ファイバ長を短 くすれば，レーザーパルスは短くすることができる。し かしながら，レーザーパルスが短くなると，放射光との 重なりも小さくなり，その分信号も弱くなる．信号強度 を上げるためには，アンジュレータービームラインの使 用が不可欠であると考えられる，そのときには，試料の 損傷を起こさないように，注意して実験を行う必要があ ると思われる。

次節ではフッ化バリウムにおいて内殼 2 光子励起の時間 応答を測定した結果を紹介する2).

4.2 フッ化バリウムにおける内殸励起子の寿命 第3節で観測されたフッ化バリウムの内殼励起子の寿命 を調べる目的で，2光子励起したときのオージェフリー発 光の時間応答を調べた2). Fig. 5に測定した波形を示す。 レーザー光と放射光が同時に入射したことで起こった現 象による信号を取り出すために，スペクトルを得たとき と同様，放射光とともにレーザー光を入射して得られた 時間応答の波形から，レーザー光を入射しないで得られ た時間応答の波形を引き算した。引き算による計数の減 少のため，個々の測定では問題にならない周期的なノイ ズがFig. 5ではやや目立つ. Fig. 5 (a)には放射光のエネル ギーが最低内殼励起子エネルギー $(17.2 \mathrm{eV})$ 以下の $16.9 \mathrm{eV}$ の場合を, Fig. 5 (b)には放射光のエネルギーが $19.6 \mathrm{eV}$ と 十分高く, 単独で内殼 $5 p$ 電子の伝導帯への励起が可能な 場合を示した。レーザー光子のエネルギーは3.10 eVに とった. Fig. 5（b)の場合は2つの光子エネルギーの和が $22.7 \mathrm{eV}$ になるので, 2 光子吸収により $5 p_{1 / 2}-6 p_{1 / 2}$ 励起子が生 成される (Fig. 3参照). Fig. 5 (a)の場合は放射光で局在励 起子(励起子が局在化してエネルギーを低下させたもの)が 生成され，レーザー光により局在励起子が再励起される と考えられる.

最低内殼励起子を 1 光子励起してもオージェフリー発光 は観測されないことから, 光生成された励起子が再結合 するときにはエネルギーがオージェフリー発光として放 出されることはなく, 一旦, 自由正孔と自由電子の対に 解離した後に初めてオージェフリー発光が放出可能であ ると考えられている10). $5 p-4 f, 5 p-6 p$ 内殼励起子の場合に おいても同様であると考えられる．また，放射光だけの
照射時にオージェフリー発光が観測されていて，レー ザー光の照射により, 内殼正孔形成から発光に至る過程 に何らかの変化が起こった場合，その分，もとの過程に よる発光は減ることになる，そこで，2光子励起による内 殼励起子の生成が原因となったオージェフリー発光の強 度を $I_{2}$ ，このときの内款励起子の寿命を $\kappa$ こ，レーザー 光の照射により発光過程が中断されたことによるオー ジェフリー発光の強度の減少を $I_{1}$, 自由な内殼正孔の寿命 をてとすると，レーザーにより誘起および抑制された発 光の時間応答は次の式で表すことができる.

$$
\begin{aligned}
I(t)= & \left(-I_{1} f_{\text {laser }}(t)+I_{2}\left(f_{\text {laser }}(t) f_{\mathrm{SR}}(t)\right) \otimes \exp (-t / \kappa) \kappa^{-1}\right) \\
& \otimes \exp (-t / \tau) \tau^{-1}
\end{aligned}
$$

ただし， $f_{\text {laser }}$ と $f_{\mathrm{SR}}$ はレーザーと放射光のパルス波形を，® はコンボリューション演算子を表す。発光効率は明示さ れていないが，係数 $I_{1} ， I_{2}$ に含まれているものとする. Fig. 5 (b)の実線は(7)によるフィッティングの結果を示してい る。怆通常のオージェフリー発光の寿命と同じ $1.2 \mathrm{~ns}$ とし た. 2 光子励起により生成された $6 p$ 励起子の寿命 $\kappa は 0.2 \mathrm{~ns}$ と求められた。この值はオージェフリー発光の寿命から 導かれる内殼正孔の寿命よりはずっと短く，イオン結晶 における価電子正孔と伝導带電子からなる励起子の低温 における寿命にほぼ等しい16)。

$16.9 \mathrm{eV}$ 放射光のみによる励起では局在励起子が作ら れ，自由正孔は作られないのでオージェフリー発光は観 測されない. そのため, Fig. 5 (a)の時間応答の解析では (7)式の $I_{1}$ の項は不要である。レーザーを同時照射したと きには局在励起子の励起により自由正孔と自由電子が直 接, 生成されると考えられるため, 発光の時間応答は(7) 式を簡略化した次の式で表される。

$$
I(t)=I_{3} f_{\text {laser }}(t) \otimes \exp (-t / \tau) \tau^{-1}
$$

ここで，2光子励起過程と区別するため，発光強度を $I_{3}$ と した.Fig. 5 (a)の実線は(8)によるフィッティングの結果 を示している.

このように，時間分解測定は，物質の励起一脱励起开 イクルを調べる際に有効な情報をもたらすことが示され た。

\section{5. おわりに}

第1節の中で述べたように，レーザーと放射光の併用実 験は両者の時間特性が接近したことによって，新たな局 面を迎えることとなった。この稿で紹介した実験では， フッ化バリウムやその他の物質で見られるオージェフ リー発光により2光子吸収を検出した. 励起状態からの発 光過程を持つさまざまな物質について，この測定法は適 用可能であると考えられる。

\section{謝 辞}

この稿で紹介した一連の研究は以下の方々との共同研 究である. 東純平 (佐賀大学シンクロトロン光応用研究セ 
ンター), 鎌田 雅夫 (同), 伊藤 稔 (信州大学工学部), 渡辺 雅之(京都大学大学院人間・環境学研究科), 有本收 (岡山大学理学部), 中西俊介(香川大学工学部), 伊藤 寛 (同). 実験は分子科学研究所極端紫外光研究施設 (UVSOR)における共同利用研究として行われた. 実験遂 行と小論作成に際し，ご助力いただいたすべての方に感 謝する。

\section{参考文献}

1) T. Tsujibayashi, M. Itoh, J. Azuma, M. Watanabe, O. Arimoto, S. Nakanishi, H. Itoh, and M. Kamada: Phys. Rev. Lett. 94 (2005) 076401.

2) T. Tsujibayashi, M. Itoh, J. Azuma, M. Watanabe, O. Arimoto, K. Toyoda, S. Nakanishi, H. Itoh, and M. Kamada: Phys. Stat. Sol. (c) 2 (2005) 228.

3）長澤 信方：「レーザー光学物性」(シリーズ物性物理の新展 開, 丸善, 1993) 第5.3節.

4) V. Saile, D. Rieger, W. Steinmann, and T. Wegehaupt: Phys. Lett. 79A (1980) 221.

5) R. Pizzoferrato, M. Casalboni, R. Francini, U. M. Grassano, F.
Antonangeli, M. Piacentini, N. Zema, and F. Bassani: Europhys. Lett. 2 (1986) 571.

6) T. Tsujibayashi, M. Watanabe, O. Arimoto, S. Fujiwara, M. Itoh, S. Nakanishi, H. Itoh, S. Asaka, and M. Kamada: UVSOR Activity Report 1996 (1997) 52.

7) S. Asaka, S. Nakanishi, H. Itoh, M. Kamada, M. Watanabe, O. Arimoto, T. Tsujibayashi, S. Fujiwara, and M. Itoh: Rev. Sci. Instrum. 69 (1998) 1931.

8) T. Tsujibayashi, M. Watanabe, O. Arimoto, M. Itoh, S. Nakanishi, H. Itoh, S. Asaka, and M. Kamada: Phys. Rev. B 60 (1999) R8442.

9) T. Tsujibayashi, J. Azuma, M. Watanabe, O. Arimoto, M. Itoh, S. Nakanishi, H. Itoh, and M. Kamada: UVSOR Activity Report 2004 (2005) 62.

10) M. Itoh: in Recent Research Developments in Physics Vol.4 (Transworld Research Network, Trivanduram, 2003) Chap. 11.

11) 西島和彦:「相対論的量子力学」(新物理学シリーズ13, 培風 館, 1973）第1章.

12) J. Reader and G. L. Epstein: J. Opt. Soc. Am. 65 (1975) 638.

13) G. W. Rubloff: Phys. Rev. B 5 (1972) 662.

14) M. Yuri, S. Sato, Y. Aiura, A. Yamada, H. Kato, and H. Fukutani: J Phys. Soc. Jpn. 61 (1992) 2557.

15) H. Jiang R. Pandey, C. Darrigan, and M. Rérat: J. Phys. Condens. Matter 15 (2003) 709.

16) T. Tsujibayashi, K. Toyoda, and T. Hayashi: Solid State Commun. 105 (1998) 684

ーレーザーワード

2光子分光法 (Two-photon spectroscopy)

2光子遷移を利用した分光法. 1光子による双極子遷移 の場合, 始状態と終状態の角運動量の変化 $\Delta j$ $j$ 場合 が許容であるが，2光子遷移では $\Delta j=0, \pm 2$ の場合が許容 となる. 2個の励起光子のエネルギーや入射方向 (角運動 場合と比べて豊富な情報を得ることが可能である．尖頭 值の高い短パルスレーザー光を使うと, 平均エネルギー が大きくなくても2光子遷移を比較的容易に起こすことが できる。

(辻林 徹) 